\title{
Program Pendampingan Hak Kekayaan Intelektual (Merek Dagang) Untuk Pengembangan Usaha (Usaha Penggilingan Bakso Kecamatan Medan Amplas)
}

\section{Intellectual Property Rights (Trademark) Assistance Program for Business Development (Bakso Milling Business, Medan Amplas District)}

\author{
Sri Hidayani \& Abdul Lawali Hasibuan
}

Fakultas Hukum, Universitas Medan Area, Medan

Diterima: 03 September 2020 ; Disetujui: 16 September 2020 ; Dipublish: 16 September 2020

*Corresponding Email: srihidayani83@gmail.com

\begin{abstract}
Pembahasan yang diteliti dalam Pengabdian Kepada Masyarakat ini adalah Bagaimana Pengaturan Hukum dalam Mendaftarkan Merek Pada Pembuatan Bakso Pada Usaha Penggilingan Bakso Kecamatan Medan Amplas. Bagaimana Tanggungjawab Pengusaha Terhadap Bahan Yang Digunakan Dalam Pembuatan Bakso yang belum menggunakan Merek pada Kecamatan Medan Amplas. Metode Pengabdian Kepada Masyarakat yang digunakan adalah Pengabdian Kepada Masyarakat yuridis empiris, yaitu Pengabdian Kepada Masyarakat hukum yang dilakukan dengan cara meneliti langsung ke lapangan tempat objek yang diteliti dengan melakukan wawancara.
\end{abstract}

Kata kunci: Penggilingan Bakso, Pengaturan Hukum; Mendaftarkan Merek.

\section{Abstract}

The discussion researched in this Community Service is How the Legal Regulations in Registering Trademarks in Making Meatballs in the Bakso Milling Business in Medan Amplas District. What are the responsibilities of entrepreneurs with the ingredients used in the manufacture of meatballs that have not used the mark in Medan Amplas District. The method of community service used is juridical empirical community service, namely the service to the legal community which is carried out by directly examining the field where the object under study is conducted by conducting interviews.

Keywords: Meatball Milling, Legal Arrangement; Registering Trademarks

How to Cite: Hidayani, S. \& Hasibuan, A.L.. (2020). Program Pendampingan Hak Kekayaan Intelektual (Merek Dagang) Untuk Pengembangan Usaha (Usaha Penggilingan Bakso Kecamatan Medan Amplas). Pelita Masyarakat: 2 (1): 51-63. 
Sri Hidayani \& Abdul Lawali Hasibuan. Program Pendampingan Hak Kekayaan Intelektual (Merek

\section{PENDAHULUAN}

Bakso adalah salah satu makanan favorit terpopuler di Indonesia. Karenanya, sangat mudah ditemukan pedagang bakso, dari desa hingga kota, mulai dari pedagang keliling, kaki lima, hingga restoran. Usaha ini berawal dari kegemaran saya mengkonsumsi bakso. Setiap saya makan bakso, rasanya cuma seperti itu saja. Kemudian saya berinisiatif untuk membuat bakso dengan perbedaan yang unik dengan usaha bakso lainnya. Dari informasi yang saya peroleh dan menurut pemikiran saya, usaha ini akan terus berkembang dan mencapai keuntungan yang lebih karena begitu banyak penggemar bakso di seluruh daerah dan semua kalangan. Untuk menjalankan usaha ini dibutuhkan perasaan optimis dan keuletan dalam menjalankannya.

Bisnis adalah sebuah pembelajaran, dimana dibutuhkan analisa yang sangat dalam tentang prospek dan kelayakan dalam usaha tersebut. Oleh karena itu, bisnis itu harus dimulai sejak dini sehingga kita memiliki banyak waktu untuk dapat memikirkan bagaimana usaha tersebut bisa terus maju dan berkembang serta mendapatkan keuntungan yang maksimal.

Bisnis makanan seperti ini merupakan bisnis yang senantiasa bertahan dan terus berkembang seiring dengan meningkatnya kebutuhan kuliner masyarakat. Ada beberapa hal yang membuat bisnis kuliner ini akan terus berkembang yaitu makanan merupakan salah satu suatu kebutuhan masyarakat baik sebagai kebutuhan kuliner maupun sebagai jajanan dan kebutuhan pokok.

Bisnis makanan memiliki pangsa sendiri, yaitu remaja dan masyarakat pecinta kuliner. Salah satu bisnis yang sedang berkembang adalah bisnis bakso. Banyaknya penggemar bakso dari seluruh daerah dan seluruh kalangan membuat usaha ini menjanjikan untuk memberikan keuntungan yang banyak.

Bisnis Bakso yang akan saya kembangkan adalah Bakso Blank. Nama Blank sendiri saya mengarang karena memang belum mendapatkan nama yang cocok untuk digunakan. dalam bisnis bakso blank yang saya dirikan ini, saya membuat jenis bakso yang mungkin kebanyakan pedagang masih jarang untuk membuatnya. Bisnis bakso ini, saya akan menyediakan bakso dengan cita rasa dan kepuasan tersendiri bagi para konsumen. Saya akan membuat bakso dengan bebagai jenis isi bakso yang berbeda seperti isi keju, isi cabai, isi telur puyuh, dan isi daging. Mungkin untuk saat ini saya akan membuat isi bakso seperti itu, dengan seiring berjalannya usaha ini, saya akan meminta pelanggan 
untuk memberikan saran serta kritik terhadap usaha saya, berhubung saya masih awal untuk membuka usaha ini.

Bisnis bakso blank ini dengan menyewa kios yang terletak di daerah yang memiliki masyarakat yang cukup banyak dengan berbagai aktivitas membuat bisnis ini mudah dijangkau oleh konsumen dan dengan menggunakan gerobak menjadikan bisnis ini mampu mencari kosumen di berbagai tempat seperti sekolah, kampus, rumah sakit, perumahan, dll.

Banyak sekali jalan menuju kesukseskan itu tergantung dari diri kita sendiri untuk memotivasi bagaimana berjalannya usaha menjadi maju dan berkembang atau dengan membuat sebuah cikal bakal bisnis yang diharapkan mampu mengembangkan daya kreativitas dan inovasi.

Dalam menghadapi persaingan dunia usaha yang semakin ketat. Sekarang ini kita dituntut untuk dapat mengembangkan usaha , supaya usaha kita dapat maju dan besar serta menjadi pengusaha yang sukses. Definisi pengembangan usaha itu sendiri adalah terdiri dari sejumlah tugas dan proses yang pada umumnya bertujuan untuk mengembangkan dan mengimplementasikan peluang pertumbuhan. Tetapi pada kenyataanya untuk mengembangkan usaha yang pada awalnya dimulai dari nol besar atau baru memulai usaha sangatlah sulit .

Pengembangan usaha adalah "Tugas dan proses persiapan analitis tentang peluang pertumbuhan potensial, dukungan dan pemantauan pelaksanaan peluang pertumbuhan usaha, tetapi tidak termasuk keputusan tentang strategi dan implementasi dari peluang pertumbuhan usaha".

Hak Kekayaan Intelektual, disingkat "HKI" atau adalah padanan kata yang biasa digunakan untuk Intellectual Property Rights (IPR), yakni hak yang timbul bagi hasil olah pikir yang menghasikan suatu produk atau proses yang berguna untuk manusia pada intinya HKI adalah hak untuk menikmati secara ekonomis hasil dari suatu kreativitas intelektual. Objek yang diatur dalam HKI adalah karya-karya yang timbul atau lahir karena kemampuan intelektual manusia.

Secara garis besar HKI dibagi dalam 2 (dua) bagian, yaitu:

1. Hak Cipta (copyright);

a. Hak kekayaan industri (industrial property rights), yang mencakup:

b. Paten (patent);

c. Desain industri (industrial design); 
Sri Hidayani \& Abdul Lawali Hasibuan. Program Pendampingan Hak Kekayaan Intelektual (Merek

2. Merek (trademark);

a. Penanggulangan praktek persaingan curang (repression of unfair competition);

b. Desain tata letak sirkuit terpadu (layout design of integrated circuit);

c. Rahasia dagang (trade secret).

Dalam Undang-Undang No. 20 tahun 2016 Tentang Merek dan Indikasi Geografis pada Pasal 1 Ayat 2 "Merek Dagang adalah Merek yang digunakan pada barang yang diperdagangakan oleh seseorang atau beberapa orang secara bersama-sama atau badan hukum untuk membedakan dengan barang sejenis lainnya."

Melihat dari proses penggilingan bakso tersebut, kelihatan sangat mudah, siapa saja bisa melakukannya, tetapi bayangkan bila dilakukan dalam jumlah besar dan menjadi sumber mata pencaharian dari keluarga apalagi sudah lebih 10 tahun berproduksi. Hal tersebut memiliki banyak hal yang menarik untuk dibahas, sekaligus menjadi bagian dari program kemitraan masyarakat dari pengabdi.

Penggilingan bakso yang menarik untuk pengabdi adalah Penggilingan Bakso Arif yang berdomisili di Jalan Persamaan gang Arifin Sitirejo II Kecamatan MedanAmplas yang sudah berprouksi sejak tahun 1997 dan Penggilingan Bakso Warto di Pasar V Marelan yang sudah berproduksi 12 Tahun.

Mitra Pertama, Bang Arif usia 48 Tahun yang merupakan perantauan dari solo dengan isrinya di kelurahan Sitirejo II,sudah melaoni pekerjaan penggilingan bakso selama 20 tahun sejak 1997. Beroperasi setiap harinya sejak sebelum fajar sekitar jam 03.00 pagi dini hari sampai jam 21.00 wib, sekarang memiliki sedikitnya 200 mitra usaha atau pelanggan berupa penjual bakso seperti warung bakso dan penjual bakso keliling dengan ibu-ibu rumah tangga yang membutuhkan baksonya yang mereka jual Rp. $13.000 / \mathrm{kg}$.

\section{ANALISIS SITUASIONAL}

Melihat jumlah pelanggan dari penggilingan bakso, maka bang arif menghadapi persoalan luas dari ruang penggilingan baksonya dan kesiapan mesin produksinya, apalagi mesin mereka itu bergantung pada tenaga listrik, yang kita juga sama mengetahui kota Medan pernah sering menghadapi pemadaman listrik tiba-tiba tanpa pemberitahuan lebih dahulu, yang berakibat pada hancurnya usaha kecil industri rumah tangga yang kebanyakan bergantung pada energy listrik. 
Bang Arif sebenarnya sudah menyediakan mesin cadangan dengn tenaga genset, tetapi tidak menghasilkan mutu dan kuatitas bakso yang sama seperti menggunakan tenaga listrik, sehingga beliau membutuhkan mesin produksi yang mumpuni.

Bang Arif juga punya keinginan agar usaha penggilingan baksonya menjadi besar, memiliki badan usaha yang diakui menurut hukum Indonesia serta mendapat fasilitas pinjaman/modal dari Pemerintah sebagai UMKM, punya manajemen yang baik, serta produknya mendapat merek dari Pemerintah bahkan bila perlu mendapat label halal dari MUI.

Dengan persoalan tersebut, tim memilih usaha penggilingan bakso yang dikelola bang arif ini sebagai mitra pengabdian, dengan maksud dapat membantu pelaku usaha untuk legalitas usahanya tersebut menurut hukum Indonesia, sekaligus merek dagangnya sehingga dapat memperoleh bantuan modal dari Pemerintah dan labelisasi halal dari MUI. Ini Mitra Kedua Warto, 42 Tahun di Pasar V Marelan juga sudah melakoni usaha produksi penggilingan bakso sejak 12 Tahun yang lalu, memiliki persoalan yang hampir mirip, yaitu bagaimana lokasi penggilingan bakso tersebut tetap, yang selama ini menyewa, menjadi tetap, disamping kebijakan penggusuran beberapa tempat di Pasar V Marelan oleh Pemerintah Kota Medan, tentunya permasalahan modal usaha dalam hal ini.

Permasalahan yang lain adalah pembuangan limbah dari proses penggilingan bakso tempatnya berusaha, di mana bias menimbulkan dampak lingkungan hidup yang tidak baik, tidak seperti penggilingan bakso bang arif yang limbahnya langsung dibuang ke sungai batuan.

Permasalahan berikutnya tentu bagaimana bakso yang dihasilkan sudah memenuhi ketentuan kesehatan dari Pemerintah, yang kadang kala pelaku usaha tidak memiliki pengetahuan tentang standar penggunaan bahan pengawet menurut hukum Indonesia, sehingga, pelaku usaha tidak lagi mengkhawatirkan bakso mereka tidak laku.

Disamping itu, pelaku usaha penggilingan bakso ingin merek dagangnya ada serta mendapat label halal dari MUI. Berdasarkan uraian latar belakang di atas, maka peneliti tertarik akan melakukan Pengabdian Kepada Masyarakat dengan judul Pengabdian Kepada Masyarakat "Program Pendampingan Hak Kekayaan Intelektual (Merek Dagang) Untuk Pengembangan Usaha (Usaha Penggilingan Bakso Kecamatan Medan Amplas)”. 
Sri Hidayani \& Abdul Lawali Hasibuan. Program Pendampingan Hak Kekayaan Intelektual (Merek

\section{METODE PELAKSANAAN}

Sesuai dengan judul Pengabdian Kepada Masyarakat dan permasalahan yang diajukan dalam Pengabdian Kepada Masyarakat ini, maka pelaksanaannya akan dilakukan di Kecamatan Medan Amplas karena ingin mengetahui bagaimana bahan-bahan apa saja yang digunakan dan cara penggilingan serta untuk dapat memiliki izin pencantuman merek yang selama ini banyak bakso-bakso yang belum mempunyai merek.

Jenis Penelitian yang dipergunakan dalam Pengabdian Kepada Masyarakat ini adalah berupa Pengabdian Kepada Masyarakat kualitatif dengan pendekatan Pengabdian Kepada Masyarakat yuridis empiris. Metode Pengabdian Kepada Masyarakat yuridis empiris adalah Pengabdian Kepada Masyarakat hukum yang dilakukan dengan cara meneliti langsung ke lapangan tempat objek yang diteliti pada Penggilingan Bakso Di Kecamatan Medan Amplas.

Instrumen pengumpul data terbagi menjadi dua yakni untuk data primer dengan menggunakan wawancara langsung kepada pihak yang terkait dengan objek Pengabdian Kepada Masyarakat. Wawancara ini dilakukan dengan indephtinterview yaitu metode pengumpulan data melalui wawancara langsung yang dilakukan secara mendalam kepada sumber data. Adapun untukdata sekunder dari telaah berbagai literatur yang relevan dengan Pengabdian Kepada Masyarakat.

Pengumpulan data akan dilakukan melalui participant observation, studi kepustakaan, wawancara dan dokumentasi.

Participant observation melalui pengamatan langsung ke lokasi untuk mengenal secara lebih dekat dengan subjek Pengabdian Kepada Masyarakat yang dipilih, pengamatan terhadap subjek yang diteliti yang terkait dengan focus Pengabdian Kepada Masyarakat, misalnya pengamatan pada pelaksanaan perlindungan hukum terhadap parakorban dan keluarga korban yang diberikan pemerintah dan penegak hukum sebagai bentuk perlindungan hukum. Hasil Pengabdian Kepada Masyarakat pengamatan ini digunakan sebagai referensi data dalam menganalisis data Pengabdian Kepada Masyarakat.

Menelaah berbagai literatur yang relevan dengan kajian Pengabdian Kepada Masyarakat dan membandingkan beberapa tulisan ilmiah atau hasil Pengabdian Kepada Masyarakat lain yang sudah pernah dilakukan dengan subjek Pengabdian Kepada Masyarakat hampir sama. 
Wawancara adalah suatu bentuk komunikasi verbal jadi semacam percakapan yang bertujuan memperoleh informasi. (S. Nasution, 2007: 113). Maka Wawancara, dilakukan dengan sejumlah informan yang terdiri pihak Pembuatan Bakso Di Kecamatan Medan Amplas dengan cara mengajukan pertanyaan yang berpedoman kepada daftar pertanyaan yang telah di konsep sebelumnya yang berkaitan dengan judul Pengabdian Kepada Masyarakat.

Analisa data dalam Pengabdian Kepada Masyarakat ini dilakukan dengan cara teknik analisa deskriptif dengan pendekatan kualitatif. Penggunaan pendekatan kualitatif ini adalah dengan pertimbangan: 1) Teknik analisa kualitatif lebih mudah apabila berhadapan dengan kenyataan ganda, 2) Teknik ini menyajikan secara langsung hakekat hubungan antara peneliti dengan responden, dan 3) Metode ini lebih peka dan lebih dapat menyesuaikan diri dengan banyak penajaman pengaruh bersama dan terhadap pola-pola nilai yang dihadapi (Moleong, 2004:5).

Semua data yang telah terkumpul dari hasil pengamatan peserta (participant observation), studi kepustakaan, wawancara dan dokumentasi, dipilah atas dasar realibilitas dan validitasnya. Selanjutnya diadakan reduksi data, dimana pada tahap ini peneliti memusatkan perhatian pada data lapangan yang telah terkumpul. Data-data yang terpilih akan disederhanakan dalam arti mengklasifikasikan data dan melakukan abstraksi data kasar tersebut menjadi uraian singkat atau ringkasan. Hal ini untuk memperjelas dan menyatukan data sehingga mempermudah dalam manganalisa data. Kemudian menggambarkan hubungan antara variabel yang satu dengan variabel lain yang diteliti agar dapat menggambarkan fenomena tertentu secara lebih konkret dan terperinci. Selanjutnya diberikan interprestasi melalui kaedah-kaedah hukum positif yang berhubungan dengan pembahasan dan menghasilkan Pengabdian Kepada Masyarakat setelah itu menarik kesimpulan.

\section{HASIL KEGIATAN}

\section{Pengaturan Hukum dalam Mendaftarkan Merek Pada Pembuatan Bakso Pada Usaha Penggilingan Bakso Kecamatan Medan Amplas.}

Cara Pendaftaran Hak Merek Proses pendaftaran hak kekayaan intelektual kini semakin mudah karena dapat dilakukan secara online. Mulai 17 Agustus 2019, Direktorat Jenderal Kekayaan Intelektual (DJKI) sudah menyediakan fasilitas yang memungkinkan pendaftaran hak merek, desain industri dan paten secara online. Pengurusan hak merek, 
Sri Hidayani \& Abdul Lawali Hasibuan. Program Pendampingan Hak Kekayaan Intelektual (Merek

desain dan paten secara daring itu dapat dilakukan melalui aplikasi pendaftaran kekayaan intelektual (KI) online. Aplikasi tersebut diluncurkan tepat pada peringatan hari kemerdekaan RI ke-74 pada tahun ini. "Masyarakat tidak lagi harus membawa banyak dokumen permohonan. Pendaftaran juga bisa di kantor masing-masing konsultan atau masyarakat dari kalangan mana saja, tidak perlu ke kantor DJKI," kata Direktur Jenderal Kekayaan Intelektual (Dirjen KI), Freddy Harris di Jakarta, Sabtu (17/8/2019) lalu.

Berikut ini akan dijelaskan tata cara pengajuan hak merek secara online maupun offline.

Pendaftaran Hak Merek secara Offline Proses pendaftaran Hak Merek ke DJKI secara manual (non-elektronik/offline) dapat dilakukan dengan cara-cara sebagaimana di bawah ini:

1. Mengajukan permohonan kepada DJKI dengan melengkapi persyaratan.

2. Permohonan pendaftaran Hak Merek diajukan dalam 2 rangkap (dokumen), diketik dengan bahasa Indonesia, serta memakai formulir yang disediakan DJKI.

3. Formulir permohonan Hak Merek memuat sejumlah data, yakni:

4. Tanggal, bulan dan tahun permohonan;

5. Nama lengkap, kewarganegaraan, dan alamat pemohon;

6. Nama lengkap dan alamat kuasa, apabila permohonan diajukan melalui kuasa;

7. Warna-warna apabila Merek yang dimohonkan memakai sejumlah unsur warna;

8. Nama negara dan tanggal permintaan pendaftaran Merek pertama kali (jika diajukan dengan hak prioritas).

9. Surat permohonan pendaftaran Hak Merek dilampiri sejumlah dokumen, yaitu:

10. Fotokopi KTP (Bagi pemohon asal luar negeri harus memilih kedudukan di Indonesia, bisa alamat kuasa hukum);

11. Fotokopi akte pendirian badan hukum yang disahkan notaris (jika permohonan atas nama badan hukum);

12. Fotokopi peraturan pemilikan bersama, jika permohonan diajukan atas nama lebih dari 1 orang (Merek kolektif);

13. Surat kuasa khusus jika permohonan pendaftaran dikuasakan;

14. Tanda pembayaran biaya permohonan; Sepuluh helai etiket Merek (ukuran maksimal $9 \times 9 \mathrm{~cm}$, minimal $2 \times 2 \mathrm{~cm}$ );

15. Surat pernyataan bahwa Merek yang dimintakan pendaftaran adalah milik pemohon. 
Sedangkan alur proses pengajuan permohonan pendaftaran Hak Merek di DJKI bisa dilihat melalui link ini.

Pendaftaran Hak Merek secara online Pengajuan pendaftaran Hak Merek secara online bisa dilakukan melalui aplikasi Merek yang disediakan oleh DJKI. Langkah-langkah yang perlu dilakukan adalah sebagai berikut.

1. Sebelum memakai aplikasi Merek, pengguna wajib memesan kode billing (nomor pembayaran) di Simpaki.

2. Untuk memesan kode billing, buka situs simpaki.dgip.go.id dan isi kolom yang tersedia.

3. Setelah pemesanan kode billing dilakukan, lakukan pembayaran

4. Setelah itu, login ke Aplikasi Merek

5. Jika belum punya akun Aplikasi Merek, lakukan registrasi akun/aktivasi e-filing terlebih dahulu

6. Aplikasi Merek sudah terintegrasi dengan Simpaki untuk pengecekan kode billing

7. Setelah login ke aplikasi, masukkan data permohonan merek, kemudian submit data permohonan online

8. Data permohonan yang sudah disubmit dapat dicetak dan akan dicek oleh petugas

9. Panduan lengkap pengajuan permohonan lewat aplikasi Merek bisa diakses melalui link ini

10. Panduan lengkap penggunaan efiling dapat dilihat melalui link ini.

Tarif Pendaftaran Hak Merek Bagi UMKM dan Umum Ketentuan tarif pendaftaran Hak Merek di DJKI (Ditjen KI) telah diatur dalam PP Nomor 28 Tahun 2019. Tarif tersebut termasuk dalam kategori Penerimaan Negara Bukan Pajak (PNBP). Besaran tarif pendaftaran Hak Merek dibedakan berdasarkan kategori pemohon, yakni umum atau UMKM, dan sarana pengajuan permohonan, yaitu secara online atau offline. PP Nomor 28 Tahun 2019 juga mengatur besaran tarif perpanjangan jangka waktu perlindungan merek. Detail nilai tarif untuk pengurusan Hak Merek adalah sebagai berikut: I. Tarif Permohonan Pendaftaran Merek 1. Tarif pendaftaran Hak Merek untuk UMKM: Rp500.000 (secara online) dan Rp600.000 (secara manual/offline) 2. Tarif pendaftaran Hak Merek untuk Umum: Rp1.800.000 (secara online) dan Rp2000.000 (secara manual/offline) II. Tarif Perpanjangan Jangka Waktu Perlindungan Merek 1. Dalam jangka waktu 6 bulan sebelum atau sampai berakhirnya perlindungan merek: a. Tarif untuk UMKM: Rp1.000.000 (perpanjangan secara online) dan Rp1.200.000 (perpanjangan manual/ offline) b. Tarif untuk Umum: Rp2.250.000 (secara online) dan Rp2.500.000 (secara manual/offline). 2. 
Sri Hidayani \& Abdul Lawali Hasibuan. Program Pendampingan Hak Kekayaan Intelektual (Merek

Dalam jangka waktu paling lama 6 Bulan setelah berakhirnya perlindungan merek: a. Tarif untuk UMKM: Rp2.000.000 (perpanjangan secara online) dan Rp2.400.000 (perpanjangan manual/offline) b. Tarif untuk Umum: Rp4.500.000 (secara online) dan Rp5.000.000 (secara manual/offline).

Apabila yang akan didaftar berupa merek 3 (tiga) dimensi, maka label merek yang dilampirkan dalam bentuk karakteristik dari merek tersebut yang berupa visual dan deskripsi klaim pelindungan. Untuk pendaftaran merek suara, label merek yang dilampirkan berupa notasi dan rekaman suara. Apabila merek suara tersebut tidak dapat ditampilkan dalam bentuk notasi, maka label merek yang dilampirkan dalam bentuk sonogram. Untuk pendaftaran merek hologram, maka label merek yang dilampirkan berupa tampilan visual dari berbagai sisi.

Dalam hal permohonan telah memenuhi persyaratan dokumen, maka permohonan tersebut akan diberikan tanggal penerimaan, dan kemudian diumumkan oleh Ditjen HKI dalam Berita Resmi Merek selama 2 (dua) bulan. Pada masa pengumuman tersebut, setiap pihak dapat mengajukan keberatan tertulis kepada Ditjen HKI sehubungan dengan permohonan pendaftaran merek tersebut.

\section{Pemeriksaan Substantif.}

Setiap permohonan akan dilakukan pemeriksaan terhadap kelengkapan dokumen persyaratan. Pemeriksaan dilakukan paling lama 15 (lima belas) hari terhitung sejak tanggal penerimaan. Dalam hal berdasarkan hasil pemeriksaan, permohonan dinyatakan lengkap dan telah melampaui jangka waktu pengumuman, permohonan dilakukan pemeriksaan substantif oleh pemeriksa. Pemeriksaan substantif dilakukan dalam jangka waktu paling lama 150 (seratus lima puluh) hari. Apabila tidak ada keberatan ataupun komentar dari pemeriksa maka hasil pemeriksaan harus diumumkan di Berita Resmi Merek selama dua (2) bulan. Pada tahap ini, publik dapat memberikan keberatan terhadap merek yang diumumkan dengan memberikan pemberitahuan tertulis. Namun, apabila tidak ada keberatan maka dalam waktu 30 (tiga puluh) hari sebelum berakhirnya masa pengumuman, Ditjen HKI dapat menerbitkan sertifikat merek.

Seorang pengusaha juga memiliki tanggung jawab yang harus ditanggungnya. Sebagai seorang pengusaha, tanggung jawab yang ditanggung tentunya sangat luas. Selain tanggung jawab terhadap bisnisnya, seorang pengusaha juga memiliki tanggung jawab terhadap pegawainya, masyarakat yang ada di lingkungan bisnisnya, juga tanggung jawab 
terhadap lingkungan. Tanggung jawab pengusaha ini sering disebut sebagai tanggung jawab sosial perusahaan atau corporate social responsibility (CSR).

Sesuai dengan namanya, CSR merupakan bentuk tanggung jawab pengusaha dan perusahaan yang tidak hanya membuat keputusan berdasarkan aspek keuntungan ekonomi, namun juga melalui pembangunan berkelanjutan dalam bidang sosial. Tanggung jawab perusahaan dalam bentuk CSR dilakukan karena perusahaan menyadari jika dalam sebuah bisnis, tidak hanya keuntungan yang bias didatangkan oleh perusahaan, namun juga kerugian bagi lingkungan dan masyarakat sekitar. Dengan kata lain, CSR dapat pula dikatakan sebagai kontribusi perusahaan terhadap tujuan pembangunan berkelanjutan melalui manajemen dampak, yakni meminimalisasi dampak negatif dan memaksimalisasi dampak positif terhadap seluruh pemangku kepentingan perusahaan.

\section{PEMBAHASAN}

Tanggung jawab Pengusaha Terhadap Bahan Yang Digunakan Dalam Pembuatan Bakso yang belum menggunakan Merek pada Kecamatan Medan Amplas.

Bentuk tanggung jawab perusahaan terhadap konsumen dapat diwujudkan dengan menyediakan produk yang berkualitas dan dengan harga yang sesuai. Konsumen memiliki hak untuk memperoleh produk yang aman, memperoleh informasi mengenai produk yang digunakan, hak untuk didengarkan dan hak untuk memilih apa yang hendak dibeli. Tanggung jawab perusahaan terhadap konsumennya juga termasuk dengan memperhatikan etika dalam beriklan, antara lain dengan tidak membuat janji-janji tentang sebuah produk yang tidak ditepati oleh perusahaan.

Adapun tanggungjawab perusahan penggilingan bakso yang dikecamatan Medan Amplas apabila konsumen yang menggilingkan daging sapi maupun ayam untuk dikelola menjadi bakso mengalami bauk yang tidak enak atau rasa daging tidak sesuai dengan yang diberikan pihak konsumen maka pihak perusahaan penggilingan tersebut akan mengganti bahan yang digunakan oleh konsumen dan meminta maaf kepada pihak konsumen yang dirugikan.

\section{SIMPULAN}

Pengaturan hukum dalam mendaftarkan merek pada pembuatan bakso pada usaha penggilingan bakso kecamatan medan amplas dengan Cara Pendaftaran Hak Merek Proses pendaftaran hak kekayaan intelektual kini semakin mudah karena dapat dilakukan secara 
Sri Hidayani \& Abdul Lawali Hasibuan. Program Pendampingan Hak Kekayaan Intelektual (Merek

online. Mulai 17 Agustus 2019, Direktorat Jenderal Kekayaan Intelektual (DJKI) sudah menyediakan fasilitas yang memungkinkan pendaftaran hak merek, desain industri dan paten secara online. Pengurusan hak merek, desain dan paten secara daring itu dapat dilakukan melalui aplikasi pendaftaran kekayaan intelektual (KI) online.Dengan pendaftaran Hak Merek di DJKI (Ditjen KI) telah diatur dalam PP Nomor 28 Tahun 2019.

Tanggungjawab pengusaha terhadap bahan yang digunakan dalam pembuatan bakso yang belum menggunakan merek pada kecamatan medan amplas adalah perusahan penggilingan bakso yang dikecamatan Medan Amplas apabila konsumen yang menggilingkan daging sapi maupun ayam untuk dikelola menjadi bakso mengalami bauk yang tidak enak atau rasa daging tidak sesuai dengan yang diberikan pihak konsumen maka pihak perusahaan penggilingan tersebut akan mengganti bahan yang digunakan oleh konsumen dan meminta maaf kepada pihak konsumen yang dirugikan.

\section{UCAPAN TERIMAKASIH}

Tim Pengabdian Kepada Masyarakat ingin berterima kasih kepada Pengurus Yayasan Pendidikan Haji Agus Salim Universitas Medan Area dan Rektor Univeristas Medan Area yang telah memberikan dukungan penuh terhadap kegiatan ini dalam bentuk bimbingan dan materi sehingga kegiatan ini dapat berjalan sesuai yang direncanakan.

\section{DAFTAR PUSTAKA}

Amaruddin, Z. A. (2010). Pengantar Metode Pengabdian Kepada Masyarakat Hukum. Jakarta: Rajawali Pers. Nasution, S., (2007), Metode Research (Pengabdian Kepada Masyarakat Ilmiah), Bumi Aksara, Jakarta. Raharjo, S, (2000), Ilmu Hukum, Bandung: PT. Citra Aditya Indriyanto, A. (2016), Aspek Hukum Pendaftaran Merek, Raja Grafindo Persada Wibowo, (2006), Menejemen Kinerja, Rajawali Perss

Bakso, Tasty Indonesian Food, diakses dari tasty Indonesian food.com

Hunaefi D, Taqi FM, Syamsir E, Muhandri, T. Subarna, Adawiyah DR, Herawati D Nurwulandari, kusnandar F., (2014), Penuntun Praktikum: Tekologi Pengolahan Pangan, Bogor (ID), Departemen ITP, FATETA, IPB

Pramudya G. Yuwono SS. (2014), Penentuan Atribut mutu tekstur bakso sebagai syarat tambahan dalam SNI dan pengaruh lama pemanasan terhadap tekstur bakso, jurnal Pangan dan Agro industry 2 (4) : 200209.

Standar Nasional Indonesia SNI 7266-2014 mengenai bakso ikan diakses dari www.bsn.go.id

Standar Nasional Indonesia SNI 3818-2014 mengenai bakso daging, diakses dari wwW.bsn.go.id.

Undang-Undang Nomor 20 Tahun 2016tentang Merek dan Indikaso Giografis

Undang-Undang Nomor 8 Tahun 1999 tentang Hukum Perlindungan Konsumen 